\title{
Types of parent-child relationship and indicators of neuropsychological development of preschool children
}

\author{
Ekaterina Ermolova, Olga Shamshikova
}

Novosibirsk State Pedagogical University, Novosibirsk, Russia

\begin{abstract}
Introduction: During the last 20 years, in Russia and in many EU countries, there has been significant change in the global social and cultural situation. Individualistic tendencies rose sharply and there is a widespread destruction of the sense of belonging. In this regard, the type of parent-child relationship is changing, which is one of the key dimension of the neuropsychological development of children. There is a logical question for psychologists, teachers and parents, what types of parent-child relationships are constructive, that is, they fovor normal neuropsychological development of children of preschool age (6-7 years).
\end{abstract}

Purpose: The purpose of the present work is to investigate correlation between types of parentchild relationships and indicators of neuropsychological development of children, as well as identifying constructive types of parent-child relationships for the normal neuropsychological development of children.

Methodology: The study was conducted within the framework of the basic screening program (pre-school stage). The Order of the Ministry of health of the Russian Federation of 03.07.2000 № 241 On approval of the Medical card of the child for educational institutions (together with the Instruction on the procedure of an accounting form № 026/u-2000 (The Medical card of the child for educational institutions of preschool, primary, basic, secondary (complete) general education, primary and secondary vocational education, orphanages and boarding schools). Determination of the correspondence of neuropsychological development to the child's age was carried out according to the following indicators: thinking and speech; attention and memory; positive emotions and social contacts; sensorimotor development. Types of parental relationship was studied using the methodology of the Questionnaire "Parental relationship" (QPR), A.Y. Varga, V.V. Stolin. The sample was formed from 94 respondents who were screened in the framework of the basic screening program (preschool stage) at the health Center of the MC "Gubernia" in Novosibirsk. The study of determination of the type of parent-child relationship of 47 respondents (mothers) was conducted and the neuropsychic development of 47 children of preschool age in the families (6-7 years) was evaluated.

Results and Discussion: The data obtained indicate that different types of parent-child relationship such as "Cooperation" and "Symbiosis" positively interrelated with different indicators (attention and memory; the development of positive emotions and the presence of significant experiences in children) of the child's neuropsychological development. Such types of parentchild relationship as "Infantilism" and "Acceptance-rejection" negatively interrelated with such indicators of child's neuropsychological development as attention and memory; thinking, speech and positive emotions and social contacts.

Conclusion: Children in groups with a more "constructive" parental relationship type have higher cognitive scores and fewer behavioral problems. The materials of the study can be used by child psychologists in the evaluation of neuropsychological development of the child. The Bank of diagnostic techniques that quickly allow diagnosing the state of neuropsychic development of the child in relation to the type of parental relations and thereby increasing the effectiveness of its correction through work with parents is of practical importance 


\section{Keywords}

Mental health, parent-child relations; neuropsychic development; preschool age; indicators of development.

Address for correspondence:

Ekaterina Ermolova, Professor of the Department of General Psychology and History of psychology, Head of the Scientific Laboratory of "Developmental Psychology", Novosibirsk State Pedagogical University, Novosibirsk, Russia.. e-mail: shamka05@mail.ru

This work is licensed under a Creative Commons Attribution-

NonCommercial 4.0 International License (CC BY-NC 4.0).

\section{(c) (i) (9)}

Submitted for publication: 3 July 2020

Received: 3 July 2020

Accepted for publication: 20

October 2020

(C)Copyright: Ermolova, Shamshikova, 2020

Licensee NDSAN (MFC- Coordinator of the NDSAN), Italy

DOI: http://doi.org/10.32437/mhgcj.v3i1.94

\section{Introduction}

"Each cultural and historical epoch gives rise to a certain set of life dominants which human community perceives as a norm, a way of life and a dominating world outlook. The modern era in this respect is a crisis one" (Shamshikova et al, 2011. p. 17). The crisis (socio-economic) manifests itself as a violation of the normal functioning of society as a result of a sharp aggravation of social contradictions and creating a threat to the resilience of both society and the individual in the environment (with the most vulnerable is the personality of a child of preschool age).

Over the past 20 years, there has been a sharp change in the system of value orientations, increased individualistic trends, there is a widespread destruction of a sense of belonging; new systems of interaction appear and space "without borders expands". In this regard, there is an urgent question of studying a "new social reality", which changes the content of growing up (development and socialization) of a child. "Specific data collected by scientists show that the change of historical situation has stimulated the qualitative mental, psychological and personality changes of a contemporary child" (Feldstein, 2011, p. 385).

The irrepressible penetration of modern means of communication and information technologies into the world of childhood; the emergence of new inflated social expectations and requirements in relation to the intellectual skills of a child; visible predominance of acceleration over amplification (enrichment of development); the change in the content and form of education at different stages of the educational process (Obukhova \& Kotlyar, 2011) demand today the need for in-depth study of the normal (potential) neuropsychological development (NPD) of a child. "... this potential of preschool childhood could be realized, as was noted by A.V. Zaporozhets, only by taking into account the age-related psychophysiological characteristics and psychological specificity of this childhood stage" (Bolshunova \& Ermolova, 2016, p. 377).

First, such consideration of the specifics of age should be carried out by parents in the organization of the system of activity of the child, its development and education. This requires that parents have certain role competencies and have sufficient motivation to maintain adequate parent-child relationships (Grusec \& Danyliuk, 2019). However, modern parents are increasingly exhibiting "low level of parental motivation, poor command of communication skills in parents in regard with children, poor organization of child's leisure and daily schedule" (Feldstein, 2011, p. 386). Such parental characteristics are reflected in different types of parental relationship (which is the basis of the social situation of development) and determine specific configurations of the development of neuropsychic processes and personal formations of preschool children.

Taking into account the relevance of the revealed contradictions, we consider it important in the current socio-cultural conditions to study the normal neuropsychological development of the child and the causes of abnormalities in the neuropsychic development of children, where one of the determining role of the functioning of the personality of a preschooler is the type of parent-child relations.

\section{Purpose}

The purpose of the present work is to investigate correlation between types of parentchild relationships and indicators of neuropsychological development of children, as well as identifying constructive types of parentchild relationships for the normal neuropsychological development of children. 


\section{Design/Methodology/Approach}

We have formed a set of complementary empirical methods: questionnaires, testing (blank and projective), mathematical and statistical methods of data processing. The study was conducted within the framework of the basic screening program (pre-school stage). The Order of the Ministry of health of the Russian Federation of 03.07.2000 № 241 On approval of the Medical card of the child for educational institutions (together with the Instruction on the procedure of an accounting form № 026/U-2000 (The Medical card of the child for educational institutions of preschool, primary, basic, secondary (complete) general education, primary and secondary vocational education, orphanages and boarding schools) (2000). Determination of the correspondence of neuropsychological development to the child's age was carried out according to the following indicators: thinking and speech; attention and memory; positive emotions and social contacts; sensorimotor development.

The following methods were used for diagnostic purposes:

1) The Questionnaire "Parental relationship" (QPR), A.Y. Varga, V.V. Stolin (1982) (DYa Raygorodsky, 1998); 2) The Orientation test of school maturity of Core-Yerseke, which is a modification of the test of A. Kern (1978); 3) Methods of learning ten words by A.R. Luria (1973); 4) Methods of "Nelepitsa (Nonsense)", the author is S.R. Nemov (1986); 5) The Interview - "A Magic world", the author is D.V. Lubowski (1982); 6) The Test "Draw a family", the authors are V. Huls (1952), L. Corman (1964) A. I. Zakharova (1982) and others (I. Kniginoy, 1998). When analyzing the results of the study, statistical data processing methods were used: percentage distribution of the trait and the correlation analysis (nonparametric rs-Spearman criterion).

The sample was formed from 94 respondents who were screened in the framework of the basic screening program (preschool stage) at the health Center of the MC "Gubernia" in Novosibirsk. The study of determination of the type of parent-child relationship of 47 respondents (mothers) was conducted and the neuropsychic development of 47 children of preschool age in the families (6-7 years) was evaluated.

\section{Results}

With the help of the Bank of diagnostic tools formed by us, diagnostics of preschool children and their parents (only mothers took part in research) was consistently by all methods carried out. We received the following results:

- in terms of intellectual and sensorimotor development screened preschoolers were divided into three groups: ready for school $60 \%$ (28 children), the average level of readiness $36 \%$ ( 17 children) and $4 \%$ of cases ( 2 children) require additional research to obtain more objective data;

- by indicators of thinking and speech: high level is revealed at $23 \%$ of cases ( 11 children), average level $-68 \%$ of cases (32 children), at $9 \%$ of cases ( 4 children) - low;

- according to the indicators of attention and memory: high level of development was revealed at $23 \%$ of the screened ( 11 children), the average level - 68\% (31 children), low level was demonstrated by $9 \%$ of children ( 5 children);

- in terms of the degree of manifestation of positive emotions and social contacts: high degree is observed at $29 \%$ (14 children), an average - $60 \%$ (28 people), low - at $11 \%$ of cases (five children);

- in terms of the level of severity of needs, strong emotions at the screened children: highly formed at $21 \%$ ( 10 children), medium - 60\% (28 children), low $-19 \%$ of cases ( 9 children).

In the study of the type of parental relationship $(\mathrm{PR})$, it was found that in terms of the scale "Acceptance - rejection" (reflects the integral emotional attitude to the child) refers to $29 \%$ of the screened parents (14 people), to the PR "Cooperation" - 8\% (4 parents), "Symbiosis" - 4\% (2 parents), "Authoritarian hypersocialization" - 8\% (4 parents), "Infantilism" was detected in $12 \%$ of cases (6 parents). In $20 \%$ of cases, the subjects were found to have a combination of types of PR scales "Acceptance - rejection and Infantilism" and "Cooperation and Symbiosis".

Thus, the most common types of PR were: a combination of scales: "Acceptance - rejection" and "Infantilism" - 20\%; "Cooperation" and "Symbiosis" - 20\% and "Acceptance - rejection" $-28 \%$.

Next, we checked the relations between the indicators of neuropsychic development of children (according to the scales of questionnaires) and the type of parent-child relationship to the child. The results of the correlation analysis by indicators of neuropsychological development and scales of parental relationship showed the following: such types of parent-child relations as "Cooperation" and "Symbiosis" directly correlate with indicators of neuropsychological development: attention and memory $(p=0,001)$, positive emotions ( $p=$ $0,001)$, strong emotions $(p=0,04)$; in addition to this type of PR "Symbiosis" has a negative relationship with the indicator of intellectual and 
sensorimotor development $(p=0,021)$. The type of parent-child relations "Acceptance-rejection" and "Infantilism" has an inverse relationship with the indicator of positive emotions $(p=0,004)$, as well as the type - «Infantilism» has an inverse relationship with the indicators of attention and memory $(p=0,01)$, strong emotions $(p=0$, 008), and the type of PR "Acceptance-rejection" has feedback with indicators of thinking and speech $(p=0,05)$.

\section{Discussion}

Based on the empirical data, we see the expediency of assessing the neuropsychic development of a child 6-7 years of age in relation to the definition of the type of parental relations. We proceed from the position that the type of parent-child relations is an integral characteristic of parental value orientations, attitudes, emotional attitude to the child (Varga, 2006; Filippova, 1999; Spivakovskaya, 2000; Holden, 1995; Shamshikova \& Gorbatovskaja, 2020), and has one of the determining effects on the level and content of neuropsychological development of the child, determining its emotional, sensorimotor and intellectual development.

The data obtained indicate that the majority of the screened children demonstrate an average level of readiness for school, i.e. the development of fine motor skills of the hand and coordination of vision and hand movements necessary for mastering writing, are able to imitate the model and focus on one case without being distracted for some time. Also, a greater number of screened children (60-68\%) have average indicators of development of arbitrary attention and short-term memory; average indicators of thinking and speech (children have elementary imaginative ideas about the world and about the logical connections and relations existing between some objects of this world: animals, their way of life, nature; demonstrate the ability to reason logically and express their thoughts grammatically correct), the average degree of positive emotions and social contacts (most children show positive experiences emotions such as joy and interest, tenderness and friendliness towards their family members; realize and accept their place in the family structure; have multiple positive social contacts and adequate structure of sexual identification). In most children, an average level of severity of needs and strong emotions was found.

However, there were children who demonstrated a low level of the examined indicators: two children - boys - showed unreadiness for school; four children were diagnosed with a low level of development of thinking and speech (these children could hardly operate with ideas about objects, connections and relations between them); five children showed a low level of development of arbitrary attention and memory. These children also found problems in relations with others.

Also, children with a high level of severity of the examined traits (according to different indicators from 10 to 14 children) were identified. These children are distinguished by active mastery of the ways of practical and cognitive activity; positive emotional attitude to the environment in accordance with the values, ideals and norms of society. In their general structure of behavior, new forms of empathy and empathy to another person, so necessary for joint activity and communication, are shown.

According to D.B. Elkonin, preschool age revolves around an adult, as around its center, its functions, and its tasks. The adult acts in a generalized form, as a carrier of social functions in the system of social relations. The child is a member of society, it cannot live outside of society, its main need is to live together with other people, but this cannot be done in current sociocultural conditions: the child's life takes place in conditions of indirect, not direct connection with the world (Elkonin, 1998; 2007). Parent plays the key role in this context.

The leadership style of the adult is important here. It should help to ensure that the child feels like a full participant in joint activities, has the opportunity to show initiative and independence in achieving the goal. Excessive regulation of the behavior of a preschool child, when he plays the role of a mechanical performer of individual orders of an adult, discourages the child, reduces his emotional tone, leaves indifferent to the results of the common cause (Obukhova, 2013).

Such types of parent-child relations as "Cooperation" (when the parent is interested in the affairs and plans of the child, tries to help him, and sympathizes; appreciates the intellectual and creative abilities of the child, feels a sense of pride for him; encourages initiative and independence of the child) and "Symbiosis" (when the parent feels with the child as a whole, tries to meet all the needs of the child, to protect him from the difficulties and troubles of life; worries for the child and seeks to devote him a lot of time) positively affect the development of such indicators of the level of neuro-mental development of the child, as attention and memory, the development of positive emotions and the presence of significant experiences in children.

Such type of parent-child relations as "Symbiosis" negatively affects the indicators of the 
level of intellectual and sensorimotor development of the child in the family. Such type of PR as "Infantilism" (when parents seek to attribute the child personal and social failure; see a child younger than his real age is and consider his interests, hobbies, thoughts and feelings not serious; imagine a child unfit and unsuccessful) is having a negative impact on such indicators of the NPD children as attention and memory, positive emotions, meaningful experiences.

The type of PR "Acceptance-rejection" (where at high scores on this scale "rejection" is diagnosed, the parent perceives his child bad, unsuitable, unsuccessful; the parent considers that the child will not succeed in life because of low abilities, small mind, bad inclinations; the parent more often feels anger, frustration, irritation, resentment towards the child) is negatively associated with such indicators of NPD as thinking and speech, positive emotions and social contacts.

\section{Conclusions}

The data obtained indicate that different types of parent-child relationship such as "Cooperation" and "Symbiosis" positively interrelated with different indicators (attention and memory; the development of positive emotions and the presence of significant experiences in children) of the child's neuropsychological development. Such types of parent-child relationship as "Infantilism" and "Acceptancerejection" negatively interrelated with such indicators of child's neuropsychological development as attention and memory; thinking, speech and positive emotions and social contacts.

As we can see, even before entering school there are differences in the cognitive, emotional and behavioral development of children, depending on the type of family relations. Children in groups with a more "constructive" parent-child type have higher cognitive scores and fewer behavioral problems. An important part of these differences between children can be explained by what parents "do" in terms of educational activities, such as parental attitudes and a style of upbringing children.

The materials of the study can be used by child psychologists in the evaluation of neuropsychological development of the child. The Bank of diagnostic techniques that quickly allow diagnosing the state of neuropsychic development of the child in relation to the type of family relations and thereby increasing the effectiveness of its correction through work with parents is of practical importance.

\section{Conflict of interest}

The authors declare no conflict of interests.

\section{References}

Shamshikova, E.O., Shamshikova, O.A., Klepikova, N.M. (2011). Isolation versus communion. Model characteristics of narcissistic personality types; Behavioral, Cognitive and Psychological Sciences Selected, peer reviewed papers from the 2011 2nd International Conference on Behavioral, Cognitive and Psychological Sciences (BCPS 2011), November 25-26. Maldives. International Proceedings of Economics Developmet and Research, 17-22.

Feldstein, D.I. (2011). A Changing Child in Changing World: Psychological and Educational Problems of the New School. Psychology in Russia: State of the Art, 4, 383396. DOI 10.11621/pir.2011.0026

Obukhova, L.F., Kotlyar, I.A. (2011). Predislovie: Razvitie. Socializaciya. Obrazovanie [Foreward: Development. Socialization. Education]. At the origins of development. Collection of scientific articles. Moscow: MGPPU, Russia. [In Russian].

Bolshunova, N.Ya, Ermolova, E.O. (2016). Possibilities of organizing education for preschool children in the forms of children's subculture. Procedia - Social and Behavioral Sciences, 233, 377-381. DOI 10.1016/j.sbspro.2016.10.162

Grusec, J.E., Danyliuk, T. (2019). Parents' Attitudes and Beliefs: Their Impact on Children's Development. In: Tremblay RE, Boivin M, Peters RDeV, eds. Tremblay RE, topic ed. Encyclopedia on Early Childhood Development. Retrieved from http://www.child-

encyclopedia.com/parenting-skills/accordingexperts/parents-attitudes-and-beliefs-theirimpact-childrens-development

The Order of the Ministry of health of the Russian Federation of 03.07.2000 № 241. (2000). On approval of the Medical card of the child for educational institutions (together with the Instruction on the procedure of an accounting form № 026/u-2000 (The Medical card of the child for educational institutions of preschool, primary, basic, secondary (complete) general education, primary and secondary vocational education, orphanages and boarding schools). Retrieved from https://sudact.ru/law/prikaz-minzdrava-rf-ot03072000-n-241/ [In Russian].

Raygorodsky, D.Ya. (1998). Prakticheskaya psihodiagnostika: ucheb. posobie [Practical 
psycho-diagnostics: studies]. Samara: Bakhrakh, Russia, 1998. [In Russian].

Kniginoy, I. (Eds.). (1998). Enciklopediya psihologicheskih testov dlya detej [Encyclopedia of psychological tests for children]. Moscow: Scientific book, Russia. [In Russian].

Varga, A.Ya. (Eds.). (2006). Sovremennyj rebenok: enciklopediya vzaimoponimaniya [Modern Child: Encyclopedia of Understanding]. Moscow: United Humanitarian Publishing House (OIG): Pragmatics of Culture, Russia. [In Russian].

Filippova, G.G. (1999). Psihologiya materinstva: konceptual'naya model': monografiya [Psychology of motherhood: conceptual model]. Moscow: Institute of Youth, Russia. [In Russian].

Spivakovskaya, A.S. (2000). Psihoterapiya: igra, detstvo, sem'ya [Psychotherapy: play, childhood, family]. Moscow: April Press: KCMO-Press, Russia, 1, 304. [In Russian].

Holden, G.W. (1995). Parental attitudes towards child-rearing. Bronstein M. (Ed.). Handbook of parenting; Mahwah, NJ: Lawrence Erlbaum Ass., 359-392.

Shamshikova O.A., Gorbatovskaja E.A. (2020). Osobennosti psihicheskih processov u mladshih shkol'nikov s raznym urovnem shkol'noj uspevaemosti [Peculiarities of mental processes of primary schoolchildren with different levels of school excellence]. Razvitie cheloveka $\mathrm{v}$ sovremennom mire. - Human development in the modern world, 2, 7-29. [In Russian].

Elkonin, D.B. (Eds.). (2007). Detskaya psihologiya [Child psychology: studies]. Moscow: Publishing Center "Academy", Russia. [In Russian].

Elkonin, D.B., Wenger, A.L. (Eds.). (1988). Osobennosti psihologicheskogo razvitiya detej 6-7-letnego vozrasta [Features of the psychological development of children 6-7 years of age]. Moscow: Pedagogy, Russia. [In Russian].

Obukhova, L.F. (2013). Vozrastnaya psihologiya: uchebnik dlya bakalavrov [Age psychology: a textbook for bachelors]. Moscow: Publishing Yurayt, Russia. [In 